\title{
Effect of Plant Row Spacing and Herbicide use on Weed Aboveground Biomass and Corn Grain Yield ${ }^{1}$
}

\author{
Efeito de Espaçamentos entre Fileiras e Uso de Herbicidas na Massa Aérea das Plantas \\ Daninhas e Produtividade de Grãos de Milho
}

ACCIARESI, H.A. ${ }^{2}$ and ZULUAGA, M.S. ${ }^{3}$

\begin{abstract}
The use of narrow plant spacing in corn (Zea mays) has been suggested as a technological alternative to obtain grain yield increases, due to a better use of resources. The regular pattern could diminish intraspecific competition while favoring interspecific competition with weeds. The objective of this study was to analyze the effect of corn row spacing on weed aboveground biomass and corn grain yield. Field experiments were conducted during 2002/ 2003 and 2003/2004 growing seasons. Three corn hybrids with two-row width $(0.70$ and $0.35 \mathrm{~m}$ ) were tested. A greater photosynthetic photon flux density (PPFD) interception with a lower weed aboveground dry matter in narrow row arrangement was obtained. Corn grain yield was greater in the narrow row arrangement than in the wide row spacing. This increase in grain yield was related to a better resource use that allows for a reduced interspecific competition. The use of reduced spatial arrangement appeared to be an interesting alternative to increase both the grain yield potential and corn suppressive ability against weeds in corn dryland production systems.
\end{abstract}

Keywords: weed cultural control, row arrangement, natural weed populations.

RESUMO - O uso de espaçamento reduzido entre fileiras de milho foi sugerido como uma alternativa tecnólogica para obter incrementos de produção de grãos devido a um melhor uso de recursos. Os arranjos regulares das culturas podem diminuir a competição entre as plantas da cultura, ao mesmo tempo que podem favorecer a competição com as plantas daninhas. O objetivo deste estudo foi analisar o efeito da modificação do espaçamento em milho sobre a produção de biomassa da parte aérea das plantas daninhas e sobre a produção de grãos da cultura. Foram conduzidos experimentos em campo durante duas estações de crescimento. Utilizaram-se três híbridos de milho com dois espaçamentos (0,70 e 0,35 m entre fileiras). Observou-se maior intercepção da radiação fotossinteticamente ativa, com menor produção de biomassa aérea das plantas daninhas no menor espaçamento. Essa maior intercepção da cultura produziu diminuição da competição das plantas daninhas, com incremento da produção de grãos de milho. O uso de espaçamento reduzido surge como uma alternativa interessante para incrementar o rendimento de milho e aumentar a habilidade da cultura em competir com plantas daninhas em sistemas produtivos não-irrigados.

Palavras-chave: controle cultural, plantas daninhas, espaçamentos entre fileiras.

\section{INTRODUCTION}

The use of equidistant planting pattern in crops has been suggested as a technological alternative to obtain grain yield increases, due to the better use of resources. Olson \& Sander (1988) suggested that the primary reason for increasing yields in narrow-row systems is the decrease of competition among corn plants for light, nutrients and water due to an equidistant

1 Recebido para publicação em 8.11.2005 e na forma revisada em 5.5.2006.

2 Professor Adjunto; ${ }^{3}$ Pesquisador Assistente, Fac. Cs. Agr. y Ftales. UNLP. CC 31. (1900). La Plata. Argentina. Comisión Investigaciones Científicas Provincia de Buenos Aires. Bs As. Argentina. 
spatial arrangement of them. However, variable results in corn planted at narrow row with important levels of nutrient and water availability were reported (Olson \& Sanders, 1988; Bullock et al., 1988; Porter et al., 1997; Westgate et al., 1997; Barbieri et al., 2000; Andrade et al., 2002; Johnson \& Hoverstad, 2002).

The regular pattern could reduce competition among crop plants while favoring competition against weeds. Crop competitive ability is an alternative to include in an integrated weed management (IWM) program (Swanton \& Weise, 1991). This increased competitiveness may result from crop breeding or better resources use by modifying row width and crop densities (Buhler, 1996). Enhancing the competitive ability of the crop by modifying plant arrangement may allow for the use of reduced herbicide rates (Johnson \& Hoverstad, 2002). Thus, an IWM program should attempt to effectively use the competitive ability of crops in suppressing weed growth, enabling the use of reduced herbicide rate to control weeds (Buhler et al., 1993).

Different studies were conducted in to compare the effect of corn planted at narrow row on weed control. Forcella et al. (1992) found that narrows row increased light interception by the crop compared to wide rows, supporting the concept that corn planted at a more equidistant plant spacing is more competitive to allow for reduced herbicide rates. Murphy et al. (1996) showed that corn planted at $50-\mathrm{cm}$ rows intercepted about 8\% more photosynthetically active radiation (PAR) at silking than crop at conventional rows, reducing biomass of late-emerging weeds. Similar results were obtained by Begna et al. (2001) in corn planted in 38-cm rows. Weed control in corn planted at $5.1 \mathrm{pl} \mathrm{m}^{-2}$ in $76 \mathrm{~cm}$ rows and at $9.8 \mathrm{pl} \mathrm{m}^{-2}$ in $38 \mathrm{~cm}$ rows where herbicide was either applied at full or one quart of the rates, the suppressive ability of weed at narrow row and high population was related to the increasing amount of light intercepted by the crop (Teasdale, 1995). However, the study did not directly compare $76 \mathrm{~cm}$-rows to $38 \mathrm{~cm}$-rows at the same plant density. Conversely, in a more recent study, Teasdale (1998) did not find any difference in the effect of row spacing on Abutilon theophrasti growth and survival. Lindquist et al. (1998) reported that corn planted in $51-\mathrm{cm}$ row spacing had little effect on Setaria faberi and Ambrosia artemisifolia control and that cultivation was the most important factor for successful use of reduced herbicide rates. Shrestha et al. (2001) showed that the effectiveness of narrow rows in reducing weed biomass was influenced by environmental conditions, time of weed emergence, weed spectrum and weed density. Although many studies were conducted to evaluate the effect of corn row spacing on different weed species, few research works have focused on comparing the effect of equidistant plant arrangement $(35-\mathrm{cm}$ rows) on natural weed populations. Therefore, the objective of this study was to evaluate the effect of corn row spacing on weed aboveground biomass and corn grain yield.

\section{MATERIAL AND METHODS}

Experiments were conducted during the $2002 / 2003$ and 2003/2004 growing seasons at the University of La Plata Experiment Station, La Plata, Buenos Aires, Argentina $\left(34^{\circ} \mathrm{S}, 58^{\circ} \mathrm{W}\right)$. The soil was a clay-loam soil, typic argiudoll, with organic matter content of $42.5 \mathrm{~g} \mathrm{~kg}^{-1}$, $18.9 \mathrm{mg} \mathrm{P} \mathrm{kg}^{-1}$ (Bray Kurtz II, 1945) and $\mathrm{pH}$ of 5.95 .

The grass weed species most commonly occurring at the site were green foxtail (Setaria verticilata), purple nutsedge (Cyperus rotundus) and bermuda grass (Cynodon dactylon). Redroot pigweed (Amaranthus quitensis), common lambsquarters (Chenopodium album), jimsonweed (Datura ferox) and field bindweed (Convolvulus arvensis) were the most common broad-leaf weeds. The weeds were distributed relatively homogenous by across the experimental site. Plots were fertilized annually at planting with $60 \mathrm{~kg} \mathrm{~N} \mathrm{ha}^{-1}$ as urea. Three single-cross hybrids (Dekalb 615, Dekalb 696 and ACA 402) were planted on October 10, 2002 and October 8, 2003 by hand. Two row widths (narrow: $35 \mathrm{~cm}$, wide: $70 \mathrm{~cm}$ between rows) at fixed plant density $\left(8.1 \mathrm{pl} \mathrm{m}^{-2}\right)$ were used. This spatial arrangement allowed to test for two corn planting patterns (quadrangular: $35 \mathrm{~cm}$ between rows and plants and rectangular: $70 \mathrm{~cm}$ between rows and $17.5 \mathrm{~cm}$ between plants). Two viable seeds were sown and the seedlings were thinned to the 
appropriate density at the four-leaf stage of corn growth. Chemical weed control was achieved with a preemergence application of a tank-mixture of atrazine plus metolachlor. Rate applied was $2.25 \mathrm{~kg}$ a.i. ha ${ }^{-1}$ of atrazine and $2.32 \mathrm{~kg}$ a.i. ha ${ }^{-1}$ of metolachlor (1:1, weed-free). Weedy plots (weedy) were also included.

Field plots were arranged in randomized blocks with four replications. Hybrids were the main plots, crop-planting patterns were patterns subplots, and the herbicides were the sub-subplots. The experimental units were $8 \mathrm{~m}$ long and five row wide.

Incident Photosynthetic photon flux density (PPFD) at the top of the canopy ( $\mathrm{I}_{\mathrm{o}}$ ) and at ground level ( $\left.\mathrm{I}_{\mathrm{g} I}\right)$ was measured at $\mathrm{V}_{4}, \mathrm{~V}_{7}, \mathrm{R}_{1}$ and $\mathrm{R}_{6}$ stages. Measurements were made under clear-sky conditions at solar noon $\pm 2 \mathrm{~h}$. $\mathrm{I}_{\mathrm{gl}}$ was measured using a linear quantum sensor (Accupar 80, Decagon Devices). The bar was placed on the soil surface (weed-free plots) or $40 \mathrm{~cm}$ above ground level (weedy plots), diagonally across two $70-\mathrm{cm}$ rows or three $35 \mathrm{~cm}$-rows at five locations in each experimental unit and averaged. $\mathrm{I}_{\mathrm{o}}$ was measured outside the canopy with a point quantum sensor (190 SB, Li-Cor, Lincoln, NE). The Percentage of PPFD intercepted $\left(\mathrm{PPFD}_{\mathrm{i}}\right)$ by the crop was calculated as:

$$
\operatorname{PPFD}_{\mathrm{i}}=\left[1-\left(\mathrm{I}_{\mathrm{gl}} / \mathrm{I}_{\mathrm{o}}\right)\right]-100
$$

Weeds were sampled in each plot (except for weed-free check plots) at the four-leaf stage $\left(V_{4}\right)$ (Ritchie \& Hanway, 1982), seven-leaf stage $\left(\mathrm{V}_{7}\right)$, flowering $\left(\mathrm{R}_{1}\right)$ and physiological maturity $\left(\mathrm{R}_{6}\right)$ of corn. Two quadrats measuring $0.25 \mathrm{~m}^{2}$ $(0.5 \mathrm{~m}$ by $0.5 \mathrm{~m})$ were established between the central two rows of each plot. Weeds were clipped at ground level, collected together and dried in a forced-air oven at $60{ }^{\circ} \mathrm{C}$ until constant weight. Weed aboveground dry matter was expressed on a per square meter basis. Corn hybrids were harvested at physiological maturity by hand picking $3 \mathrm{~m}$ of the two central rows. All samples were dried at $60{ }^{\circ} \mathrm{C}$ until constant weight. Ears were shelled and grain yield determined on a per square meter basis.

Climatic data was available from an automatized agrometeorological station, located $250 \mathrm{~m}$ from the experimental field (Table 1). Analysis of variance was used to test the effect of year, hybrids, crop planting pattern, herbicide rates and interactions. In all cases, there were significant differences among years. Thus, the data were analyzed separately by years. Weed biomass, corn above and belowground biomass and grain yield were log transformed and percentages were arcsen $(\mathrm{x}+1)$ transformed to improve homogeneity of variance for mean separation, but data were back transformed for presentation. Mean separation was calculated using Fisher's protected LSD test $(\mathrm{p}<0.05)$. Statistical package SAS 6.03 was used to perform analyses (SAS, 1988).

\section{RESULTS AND DISCUSSION}

There were no significant differences between total seasonal precipitation (SeptemberApril) and mean monthly temperature among years (Table 1). Both seasonal precipitation and monthly temperature appeared to be adequate for corn growth. However, except for September and December, monthly precipitation varied $(\mathrm{p}<0.05)$ between years (Table 1$)$. This different monthly distribution could explain the significant treatment obtained by year interactions.

Table 1 - Total monthly rainfall ( $\mathrm{mm}$ ) and mean daily temperature $\left({ }^{\circ} \mathrm{C}\right)$ during the growing seasons of 2002/2003 and 2003/2004 at La Plata National University Experiment Station

\begin{tabular}{|l|c|c|c|c|}
\hline \multirow{2}{*}{ Month } & \multicolumn{2}{|c|}{ Rainfall $(\mathrm{mm})$} & \multicolumn{2}{c|}{ Temperature $\left({ }^{\circ} \mathrm{C}\right)$} \\
\cline { 2 - 5 } & $2002 / 2003$ & $2003 / 2004$ & $2002 / 2003$ & $2003 / 2004$ \\
\hline September & 90.9 & 81.4 & 12.5 & 12.2 \\
\hline October & 67.6 & 61.6 & 17.4 & 16.4 \\
\hline November & 110.8 & 159.6 & 19.2 & 18.0 \\
\hline Necember & 60.4 & 55.0 & 20.7 & 19.8 \\
\hline Danuary & 43.6 & 101.4 & 23.3 & 22.9 \\
\hline February & 187.2 & 40.0 & 22.7 & 20.6 \\
\hline March & 66.4 & 26.2 & 20.3 & 21.0 \\
\hline Aprim & 36.2 & 165.2 & 15.3 & 17.3 \\
\hline Total & 663.1 & 690.4 & & \\
\hline Mean & & & 18.9 & 18.5 \\
\hline
\end{tabular}

\section{PPFD Interception}

The narrow row arrangement increased ( $\mathrm{p}<0.05$ ) PPFD interception, compared to 
wide row arrangement in 2002/2003 and $2003 / 2004$ (Figure 1). In the narrow row arrangement, there were no differences for the intercepted PPFD between weedy and weedfree treatments (Figure 1a, 1c). On the other hand, the weedy treatment intercepted less ( $p<0.05)$ PPFD than the weed-free treatment in the wide row spacing (Figure $1 b$, d). The weed-free narrow rows intercepted about 9 to $11 \%$ more PPFD at the flowering stage than weed-free wide rows during the two years of this study.
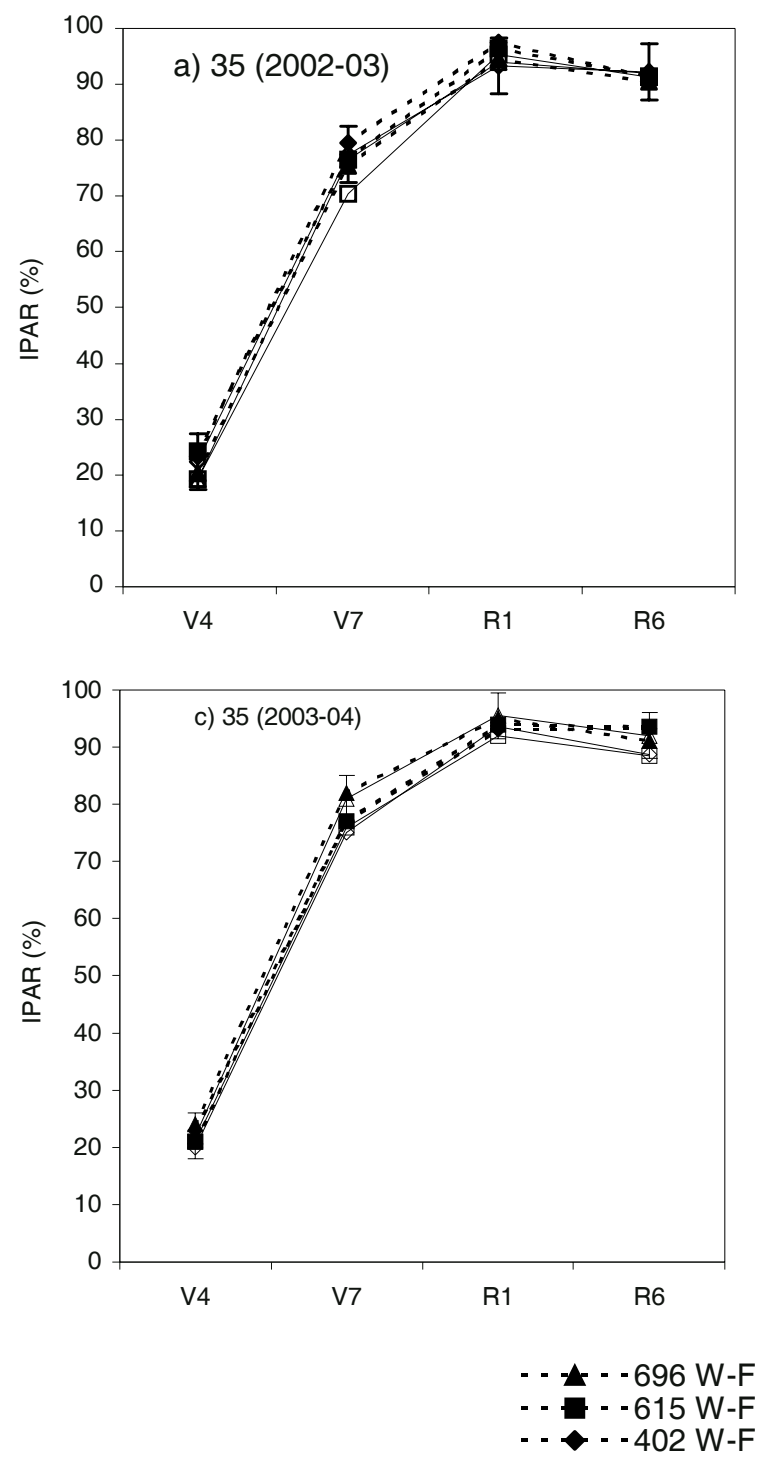

In the weedy treatment, the narrow rows intercepted about 15 to $21 \%$ more PPFD than wide rows (Figure 1). The plant arrangement $\mathrm{x}$ hybrids interaction was not significant in both years.

These results demonstrate that the higher PPFD intercepted by the crop in the narrow row arrangement has reduced weed competition and consequently could increase corn competitivity. This effect of lower interspecific competition in the narrow row
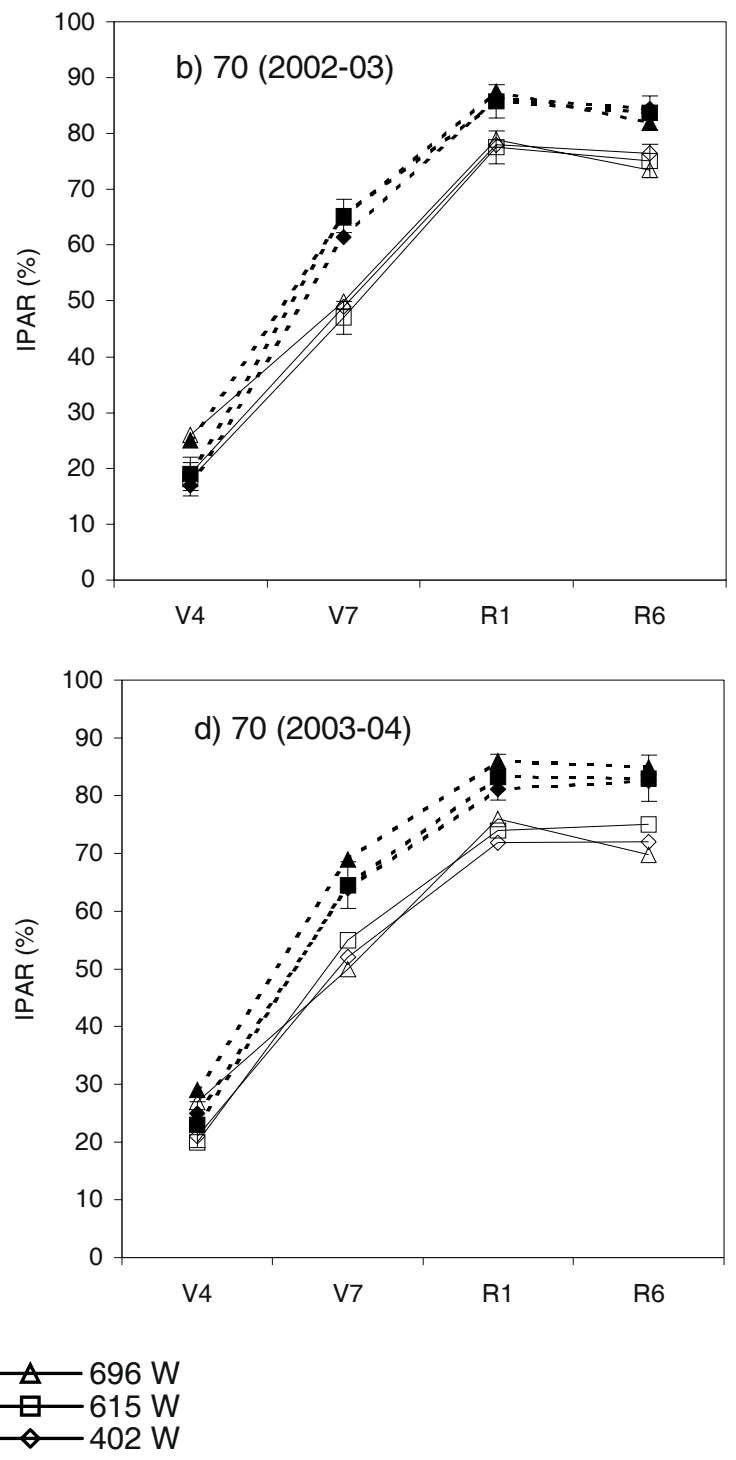

Figure 1 - Percent of photosynthetically active radiation interception (IPAR) by weed-free (W-F) and weedy (W) corn hybrids at the four-leaf $\left(\mathrm{V}_{4}\right)$, seven-leaf $\left(\mathrm{V}_{7}\right)$, flowering $\left(\mathrm{R}_{1}\right)$ and physiological maturity $\left(\mathrm{R}_{6}\right)$ stages of corn planted in narrow (35) and wide (70) row arrangement. 2002/2003 and 2003/2004 growing seasons. Vertical bars are LSDs ( $<$ 0.05) for comparing hybrid means at the same weed level. 
arrangement was visualised in the relative yield total (RYT) values. The RYT obtained at the wide row arrangement were not significantly different from 1.0, showing no resource complementarity between corn and natural weed population (data not shown). This fact is supported by the higher aboveground crop biomass obtained in the narrow plant arrangement during the corn growing cycle. This result supports the concept that a more equidistant spatial arrangement of corn plants is thought to play a role in reducing the potential for weed interference (Elmore, 1996).

Narrower rows increased PAR interception but the effect was greater for the weedy treatment. These results agree with Forcella et al. (1992), Teasdale (1995), Murphy et al. (1996) and Begna et al. (2001). However, the interception obtained in the narrow row arrangement was higher than that reported by Murphy et al. (1996) and Begna et al. (2001); Bullock et al. (1988); Teasdale (1995); Barbieri et al. (2000) and Andrade et al. (2002) reported that the greater PAR interception in narrow rows at flowering was obtained when corn growth at early stages was most limited. Barbieri et al. (2000) showed that relative grain yield responses to narrow rows decreased as crop PAR intercepted at flowering with increased wide row arrangement. In the present study, this effect was observed in corn planted at wide row arrangement with no herbicide application, where a high weed biomass was obtained. The greater PAR interception observed in narrow row arrangement in weedy conditions offsets competitive effect of weeds on PAR interception in wide row arrangement.

\section{Grain yield}

The grain yield registered in the 2002/ 2003 growing season was greater ( $\mathrm{p}<0.05)$ than that obtained in 2003/2004 growing season when full-rate broadcast application of herbicides was applied (1.0 X) (Figure 2). Considering hybrid mean values, corn grain yield was greater when crop was grown in narrow row rather than in wide row spacing in 2002/2003 and 2003/2004, regardless of herbicide application.

Grain yield was 30.0 and $33.2 \%$ greater in the narrow rows than in the wide rows in 2002/
2003 and 2003/2004, respectively (Figure 2a, b). The narrow row arrangement showed no significant differences between weedy and nonweedy treatments during 2002/2003 and 2003/2004 (Figure 2a, b). In wide rows, a lower
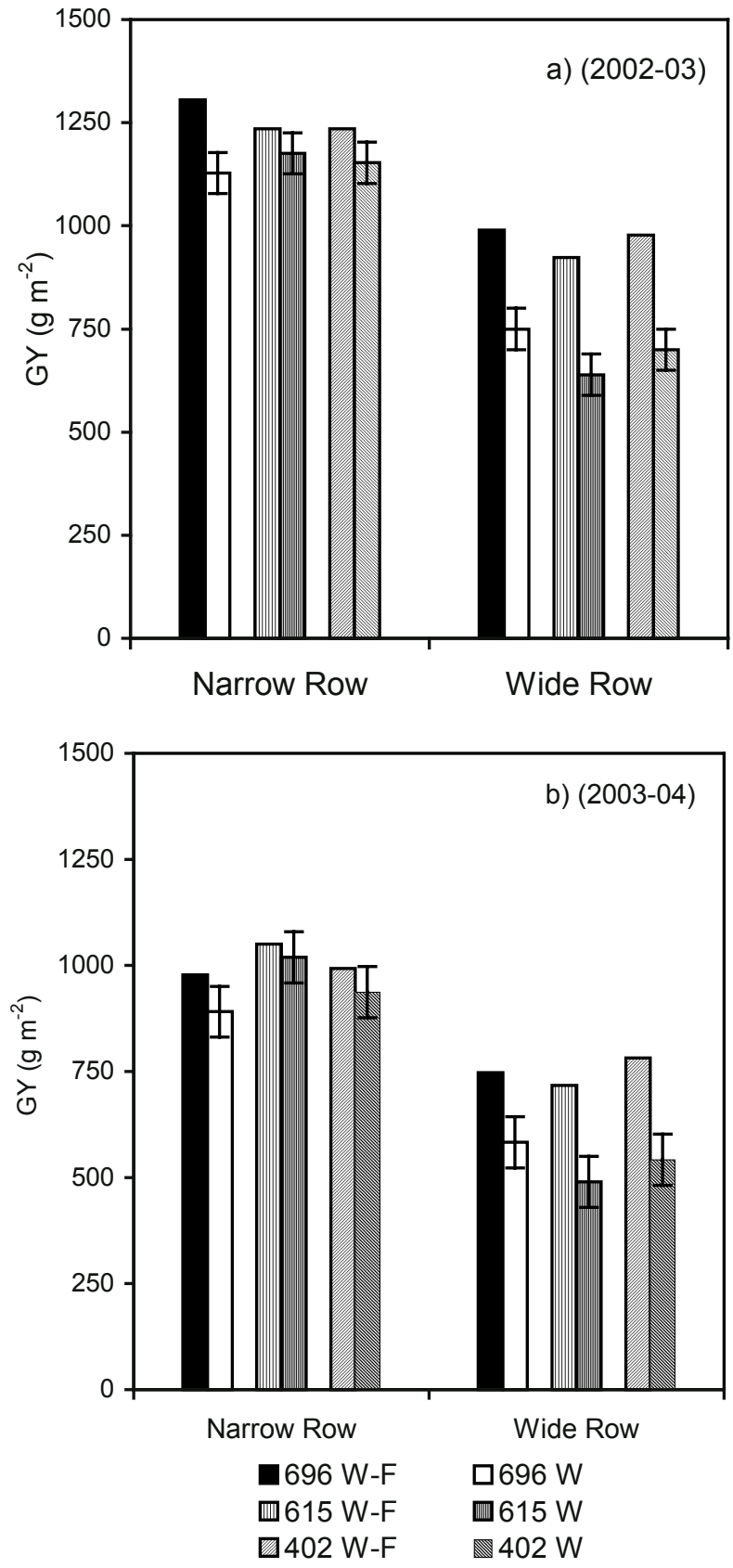

Figure 2 - Grain yield (GY, $\left.\mathrm{g} \mathrm{m}^{-2}\right)$ of weed-free (W-F) and weedy (W) corn hybrids planted in narrow and wide row arrangements during 2002/2003 and 2003/2004 growing seasons. Vertical bars are LSDs $(\mathrm{p}<0.05)$ for comparing hybrid means at the same row spacing. 
yield $(\mathrm{p}<0.05)$ was observed when no herbicide was applied (Figure 2a, b). The interaction hybrid $\mathrm{x}$ planting pattern was significant in 2002/2003 and 2003/2004.

\section{Weed aboveground dry matter}

The total weed aboveground dry matter obtained at $\mathrm{V}_{4}, \mathrm{~V}_{7}, \mathrm{R}_{1}$ and $\mathrm{R}_{6}$ stages was presented (Figure 3 ). No significant differences were found in the total weed aboveground dry matter between hybrids for both years. In $2002 / 2003$ and $2003 / 2004$, in the weedy treatment, the narrow row planting pattern registered a lower $(\mathrm{p}<0.05)$ aboveground dry matter than the wide row arrangement (Figure $3 a, b)$. The differences between planting pattern were highly significant $(\mathrm{p}<0.01)$ at flowering $\left(\mathrm{R}_{1}\right)$ and maturity $\left(\mathrm{R}_{6}\right)$, registering the narrow row arrangement a lower weed aboveground dry matter (Figure 3a, 3b). A greater $(\mathrm{p}<0.05)$ weed aboveground dry matter was observed in wide row arrangement at flowering and maturity with full-rate broadcast application of herbicides (1.0 X) (Figure 3a, 3b).

Several studies have reported the advantage of narrow rows over conventional rows for corn grain yields (Bullock et al., 1988; Porter et al., 1997; Barbieri et al., 2000). The
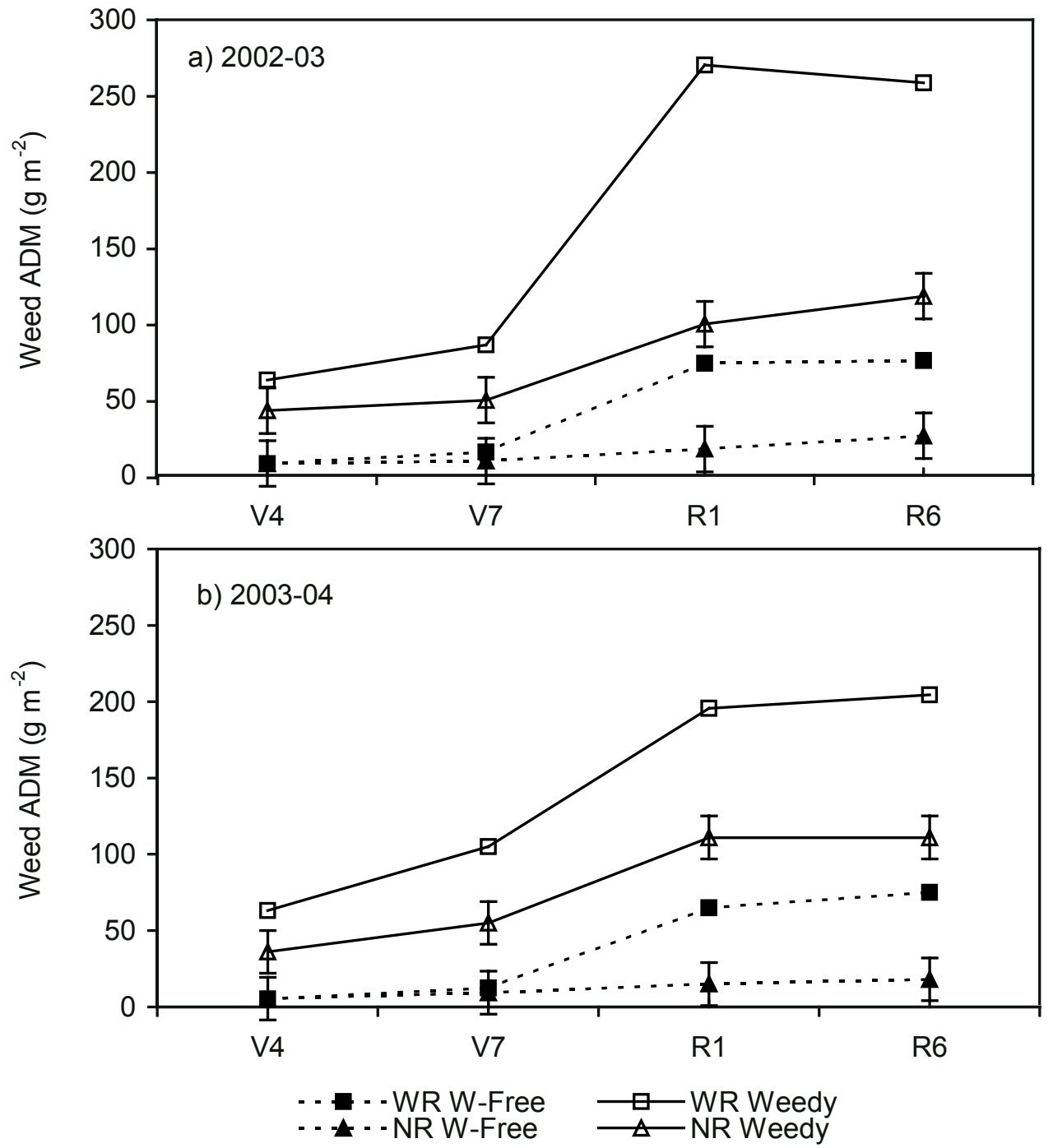

Figure 3 - Weed aboveground dry matter $\left(\mathrm{ADM}, \mathrm{g} \mathrm{m}^{-2}\right)$ at the four-leaf $\left(\mathrm{V}_{4}\right)$, seven-leaf $\left(\mathrm{V}_{7}\right)$, flowering $\left(\mathrm{R}_{1}\right)$ and physiological maturity $\left(\mathrm{R}_{6}\right)$ stages in weed-free (W-Free) and weedy corn hybrid plots planted in narrow (NR) and wide row (WR) arrangement during 2002/2003 and 2003/2004 growing seasons. Vertical bars are LSDs $(p<0.05)$ for comparing weed means at the same row spacing. 
increase in corn grain yield in narrow rows has been suggested as the decreased result of intraplant competition for resources (Olson \& Sander, 1988) and reduction in weed competition (Forcella et al., 1992; Teasdale, 1995; Murphy et al., 1996; Begna et al., 2001). Our results showed that a significant increase in grain yield could be obtained in narrow row arrangement due to a better use of resources (soil moisture and PAR interception) that allow for a reduced interspecific competition. Moreover, the higher PAR interception obtained in corn planted at narrow row increased the suppressive ability against weed of crop during $2002 / 2003$ crop and 2003/2004 growing seasons. These results are not in agreement with Lindquist et al. (1998) and Shresta et al. (2001), who stated that the effectiveness of narrow row in reducing weed biomass was related to environmental conditions and time of weed emergence. In our study, narrow row corn was equally successful in reducing aboveground dry matter in early and later emerging weeds under wet (2002/2003) and dry (2003/2004) growing conditions.

It can be concluded that the use of equidistant row arrangement allowed dryland corn to compete with natural weed population while improving the grain yield. Better PPFD interception appeared as an important factor leading to a greater crop suppressive ability against weeds.

\section{REFERENCES}

ANDRADE, F. H. et al. Yield responses to narrow rows depend on increased radiation interception. Agron J., v. 94, p. 975-980, 2002.

BARBIERI, P. A. et al. Row spacing effects at different levels of nitrogen availability in maize. Agron J., v. 92, p. 283-288, 2000.

BEGNA, S. H. et al. Weed biomass production response to plant spacing and corn (Zea mays) hybrids differing in canopy architecture. Weed Technol., v. 15, p. 647-653, 2001.

BUHLER D. D.; GUNSOLUS, J. L.; RALSTON, D. F. Common cocklebur (Xanthium strumarium) control in soybeans (Glycine max) with reduced bentazon rates and cultivation. Weed Sci., v. 41, p. 447-453, 1993.

BUHLER, D. D. Development of alternative weed management strategies. J. Prod. Agric., v. 9, p. 501-505, 1996.
BULLOCK, D. G.; NIELSEN, R. L; NYQUIST, W. E. A growth analysis comparison of corn grown in conventional and equidistant plant spacing. Crop Sci., v. 28, p. 254-258, 1988.

ELMORE, C. L. A reintroduction to integrated weed management. Weed Sci., v. 44, p. 409-412, 1996.

FORCELLA F.; WESTGATE, M. E.; WARNES, D. D. Effect of row width on herbicide and cultivation requirements in row crops. Am. J. Altern. Agric., v. 7, p. 161-167, 1992.

JOHNSON G. A.; HOVERSTAD, T. R.; GREENWALD, R. E. Integrated weed management using narrow corn row spacing, herbicides and cultivation. Agron J., v. 90, p. 40-46, 1998.

JOHNSON, G. A.; HOVERSTAD, T. R. Effect of row spacing and herbicide application timing on weed control and grain yield in corn (Zea mays). Weed Technol., v. 16, p. 548-553, 2002.

LINDQUIST, J. L.; MORTENSEN D. A.; JOHNSON, B. E. Mechanism of corn tolerance and velvetleaf suppressive ability. Agron J., v. 90, p. 787-792, 1998.

MURPHY, S. D. et al. Effects of planting pattern and interrow cultivation on competition between corn (Zea mays) and late emerging weeds. Weed Sci., v. 44, p. 856-870, 1996.

OLSON, R. A.; SANDER, D. J. Corn production. In:. SPRAGUE, G. F.; DUDLEY, J. W. Corn and corn production. Madison: ASA CSSA \& SSSA Press, 1988. p. 639-686.

PORTER, P. M. et al. Corn responses to row width and plant population in the northern corn belt. J. Prod. Agric., v. 10, p. 293-300, 1997.

RITCHIE, S. W.; HANWAY, J. J. How a corn plant develops. In: Cooperative Cary: Ames: Iowa State University Press, 1982. (Extension Service Special Report, 48).

SAS Institute. SAS/STAT User's Guide-Release 6.03. Cary: 1988.

SHRESTHA, A. et al. An integrated weed management strategy for glufosinate-resistant corn (Zea mays). Weed Technol., v. 15, p. 517-522, 2001.

SWANTON C. J.; WEISE, S. F. Integrated weed management in Ontario: the rationale and approach. Weed Technol., v. 5, p. 657-663, 1991.

TEASDALE, J. R. Influence of narrow row/high population corn on weed control and light transmittance. Weed Technol., v. 9, p. 113-118, 1995.

TEASDALE, J. R. Influence of corn (Zea mays) population and row spacing on corn and velvetleaf (Abutilon theophrasti) yield. Weed Sci., v. 46, p. 447-453, 1998.

WESTGATE, M. E. et al. Rapid canopy closure for maize production in the northern US corn belt: radiation use efficiency and grain yield. Field Crops Res., v. 49, p. 249-258, 1997. 